\title{
Równość w publicznej opiece zdrowotnej
}

\author{
Equality in public healthcare
}

\author{
Marcin Kolwitz
}

Pomorski Uniwersytet Medyczny w Szczecinie, Zakład Medycyny Społecznej i Zdrowia Publicznego, ul. Żołnierska 48, 71-210 Szczecin

\begin{abstract}
Ensuring equality in the healthcare system means that socioeconomic factors such as economic status, age, education, or place of residence should not affect the quality, timeliness and availability of healthcare for which the patient is covered. This recognizes that every citizen has the right to healthcare. This right might be mentioned both in general acts as well as legislation regulating the operation of healthcare systems.

All systems of financial constraints mean that meeting the demand for healthcare becomes possible only to a limited degree. This is the reason for systemic reforms. These reforms
\end{abstract}

are especially needed in countries that allocate a relatively small fraction of public funds to healthcare, including Poland. With the restrictions in access to healthcare it becomes necessary to increase spending by private funds. Depending on the individual system solutions, these measures may be included in the public sector (a system of subsidies or insurance) or operate in the private sector. Private funds therefore have an impact on the conditions of access to healthcare. The practical operation of healthcare systems puts the claimed equality into question. Keywords: healthcare system; healthcare providers; availability; public funds.

\section{ABSTRAKT}

Zapewnienie równości w systemie opieki zdrowotnej oznacza że czynniki socjoekonomiczne takie jak status materialny, wiek, wykształcenie, miejsce zamieszkania nie powinny wpływać na jakość, punktualność i dostępność opieki zdrowotnej, którą pacjent jest objęty. Uznaje się więc, że każdy obywatel ma prawo do opieki zdrowotnej. Prawo to może być wymienione zarówno w ogólnych aktach prawnych, jak i ustawodawstwie regulującym działanie systemów opieki zdrowotnej.

Wszystkie finansowe ograniczenia systemów powodują, że zaspokojenie popytu w zakresie opieki zdrowotnej staje się możliwe tylko w stopniu ograniczonym. Jest to powodem systemowych reform. Ich konieczność pojawia się szczególnie
\end{abstract}

w państwach przeznaczających na opiekę zdrowotną stosunkowo niskie nakłady ze środków publicznych, co dotyczy również Polski.

Przy ograniczeniach w dostępie do opieki zdrowotnej konieczne staje się zwiększanie wydatków ze środków prywatnych. W zależności od indywidualnych rozwiązań systemowych środki te mogą być włączone do sektora publicznego (system dopłat bądź ubezpieczeń) albo funkcjonować w sektorze prywatnym. Środki prywatne mają więc wpływ na warunki dostępu do opieki zdrowotnej. Praktyka działania systemów opieki zdrowotnej stawia więc pod znakiem zapytania deklarowaną równość. Słowa kluczowe: system opieki zdrowotnej; świadczeniodawcy; dostępność; środki publiczne.

\section{POJĘCIE RÓWNOŚCI}

Ochrona zdrowia obejmująca opiekę zdrowotną i działania w ramach zdrowia publicznego stała się istotnym elementem polityki społecznej realizowanej w poszczególnych krajach w XX w. Było to związane z przejmowaniem przez państwa odpowiedzialności w zakresie stanu zdrowia obywateli. Finansowanie opieki zdrowotnej ze środków publicznych stało się priorytetem tworzących się systemów zabezpieczenia społecznego i zdrowotnego.

Różnie w poszczególnych państwach ukształtował się poziom ochrony zdrowia , a także jej zakres, zarówno przedmiotowy, jak i podmiotowy. Wynikał on z modelu opieki zdrowotnej realizowanego przez dane państwo, a także z poziomu jego zamożności. Wzrastająca rola środków publicznych w finansowaniu opieki zdrowotnej miała gwarantować praktyczną realizację zasady równości będącej pochodną szerszych koncepcji tworzonych w polityce społecznej, których zdrowie jest uznawane za wartość w sensie społecznym. Kwestia równości uważana jest za jedną z podstawowych wartości w systemie opieki zdrowotnej, a jej realizacja oznacza zapewnienie i zabezpieczenie dostępu do opieki zdrowotnej wszystkim obywatelom, bez względu na kryteria różnicujące, np. ekonomiczne, społeczne, kulturowe, geograficzne [1].

Równy dostęp do opieki zdrowotnej dotyczy więc przede wszystkim osób, które są lub mogłyby być dotknięte zjawiskami określanymi jako marginalizacja i wykluczenie społeczne. Marginalizacja z powodu takich przyczyn jak niepełnosprawność, niezaradność, nieumiejętności uzyskania wiedzy dotyczącej zdrowia i zdrowego stylu życia może więc wykluczyć z korzystania z opieki zdrowotnej. Z kolei brak równego dostępu do opieki zdrowotnej, wynikający np. z niedostatecznej infrastruktury w sektorze świadczeniodawców, mógłby stać się przyczyną marginalizacji czy też wykluczenia w innych sferach 
życia społecznego [2]. Można więc wysnuć wniosek, że równość stanowi także element poszanowania godności pacjenta (założenie szwedzkiego systemu opieki zdrowotnej) [3].

Należy podkreślić, że w opiece zdrowotnej finansowanej ze środków publicznych pojęcie równości odnosi się do otrzymanych korzyści (świadczeń zdrowotnych), nie zaś do ponoszenia nakładów na opiekę zdrowotną. Tutaj decyduje zasada solidaryzmu społecznego, w której wkład finansowy obywatela (ubezpieczonego bądź podatnika) nie ma wpływu na warunki otrzymanego świadczenia. Daje jedynie uprawnienia do jego uzyskania. Wkład ten zależy zazwyczaj od osiąganego dochodu, a więc nie jest równy dla wszystkich.

\section{RÓWNOŚĆ W AKTACH PRAWNYCH}

Deklarowanie równości w ujęciu dokumentów międzynarodowych oznacza deklarację zmierzania do określonego celu. Strategia Zdrowie 21 opracowana przez Światową Organizację Zdrowia (World Health Organization - WHO) jako jeden z celów strategicznych zakłada istotną poprawę poziomu zdrowia w państwach poprzez eliminację różnic w dostępie do opieki zdrowotnej między grupami społecznymi o różnym statusie socjoekonomicznym do 2020 r. [4]. Nawiązując do strategii WHO, kwestię równości w ochronie zdrowia podjęto w umowach międzynarodowych. Najistotniejszym dokumentem jest Międzynarodowy Pakt Praw Gospodarczych, Socjalnych i Kulturalnych, w myśl którego prawo do korzystania z najwyższego osiągalnego poziomu ochrony zdrowia fizycznego i psychicznego przysługuje każdemu (niezależnie od obywatelstwa) [5]. Inne akty prawne dotyczące prawa określonych kategorii osób do opieki zdrowotnej to: art. 24 konwencji o prawach dziecka z 1989 r. [6], art. 12 konwencji w sprawie likwidacji wszelkich form dyskryminacji kobiet z 1979 r. [7], art. 25 konwencji o prawach osób niepełnosprawnych [8], art. 28, 43, 45 międzynarodowej konwencji dotyczącej ochrony praw migrujących pracowników i członków ich rodzin z 1990 r. [9], art. 24 konwencji dotyczącej statusu uchodźców z 1951 r. [10].

Wśród regulacji europejskich kwestia równości poruszona jest w art. 11 Europejskiej Karty Społecznej z 1961 r. (zrewidowanej w 1996 r.) [11] oraz w dokumencie Zmniejszanie nierówności zdrowotnych w Unii Europejskiej [12] stanowiącym o różnicach w równym dostępie do opieki zdrowotnej zarówno w poszczególnych krajach członkowskich, jak i pomiędzy poszczególnymi państwami. Na ten drugi aspekt zwraca również uwagę deklaracja W sprawie europejskiego obserwatorium zdrowia publicznego podpisana przez ministrów zdrowia nowych członków UE. Wskazuje ona na konieczność podejmowania działań zmierzających do zniwelowania różnic w stanie zdrowia mieszkańców krajów tzw. starej i nowej Europy [13].

Najistotniejszym dokumentem unijnym stanowiącym realizację zasady równości pacjentów pomiędzy poszczególnymi państwami jest tzw. dyrektywa transgraniczna, będąca elementem koordynacji zabezpieczenia społecznego w Unii Europejskiej. W dyrektywie państwa członkowskie zobowiązują się do zagwarantowania pacjentom równego dostępu do transgranicznej opieki zdrowotnej i zapewnienia im prawa do zwrotu kosztów opieki w innych państwach [14].

Zasadnicze jednak znaczenie w realizacji zasady równości na poziomie ustawodawstwa krajowego ma prawo do ochrony zdrowia. W polskim systemie prawo to zapisano w art. 68 Konstytucji pkt 2 „obywatelom, niezależnie od ich sytuacji materialnej, władze publiczne zapewniają równy dostęp do świadczeń opieki zdrowotnej finansowanych ze środków publicznych" [15].

\section{RÓWNOŚĆ A SPRAWIEDLIWOŚĆ I PRAWO DO OPIEKI ZDROWOTNEJ}

Równość rozumianą jako równy dla wszystkich dostęp do przedmiotowych zasobów opieki zdrowotnej (świadczeń) i realizacji prawa do tej opieki przez obywateli, czyli zasobów podmiotowych, można traktować jako wartość występującą łącznie ze sprawiedliwością [3]. Pojęcia równości i sprawiedliwości nie są jednak tożsame, choć nie muszą też być pojęciami przeciwstawnymi. Równość wydaje się mieć charakter bardziej obiektywny i wymierny (wszyscy podlegają tym samym zasadom) niż sprawiedliwość (może ona różnicować osoby ze względu na ich określone cechy, czyli na „równych” i „równiejszych”). Sprawiedliwość ma zazwyczaj charakter uznaniowy (może być różnie rozumiana) i jest wynikiem decyzji politycznych, które mogą określać przywileje dla określonych grup.

Czy oznacza to, że równość powinna być istotniejsza niż sprawiedliwość? Niekoniecznie, gdyż można uzasadnić wspomniane uprzywilejowanie niektórych grup, jak np. szczególną ochronę dzieci, kobiet ciężarnych, osób niepełnosprawnych, osób starszych. Istotne jest, żeby czynione wyjątki (zarówno w zakresie podmiotowym, jak i przedmiotowym) nie były rozszerzane.

Równość w ochronie zdrowia oznacza możliwość wyrównania szans (jednakowe szanse bycia zdrowym i wyzdrowienia w przypadku choroby) [16]. Wyrównanie to jest konieczne ze względu na nierówne czynniki genetyczne mające wpływ na stan zdrowia. Czynniki genetyczne czy wydarzenia losowe związane są z teorią tzw. loterii życia i stanowią element tzw. loterii naturalnej (cechy czy okoliczności, na których istnienie człowiek nie ma wpływu). W związku z tym istnieje konieczność zastosowania zasad tzw. loterii społecznej, polegającej na dystrybucji dóbr w taki sposób, aby zrównoważyć niedostatki związane z loterią naturalną.

Realizacja równości w dostępie do opieki zdrowotnej wynika z tzw. sprawiedliwości dystrybutywnej stosowanej w przypadku braku lub niedoboru dóbr (taka sytuacja ma miejsce w publicznej opiece zdrowotnej, gdyż ilość usług oferowanych w ramach tej opieki jest ograniczona). Sprawiedliwość dystrybutywna oznacza bezstronny i równy podział dóbr opierający się na zasadzie „każdemu wg potrzeb” [17].

Aby uprawniony świadczeniobiorca mógł otrzymać opiekę adekwatną do potrzeb (w odpowiednim czasie i zakresie), muszą być spełnione pewne warunki. Dotyczą one: liczebności lekarzy i innych kadr medycznych, ilości infrastruktury 
medycznej oraz odpowiednich nakładów przeznaczonych na opiekę zdrowotną przez publicznego płatnika.

Reglamentacja liczby lekarzy, niewystarczająca ilość specjalistów, limitowanie świadczeń, które wpływa na punktualność ich udzielania (kolejki do lekarzy), oraz ograniczona dostępność do specjalistów zależna od miejsca zamieszkania to zazwyczaj nieodłączne elementy publicznej opieki zdrowotnej. Jest to związane z nieograniczonym popytem na świadczenia zdrowotne i ograniczoną ilością środków publicznych przeznaczonych na finansowanie tych świadczeń. Efektem końcowym racjonowania są więc zazwyczaj: odmowa dostępu do części świadczeń i dyskryminacja niektórych pacjentów lub całych grup pacjentów [18]. Można to zaobserwować w przypadku dwóch rodzajów chorób. Pierwszy dotyczy tzw. chorób rzadkich, którymi dotknięty jest bardzo niewielki odsetek populacji, a ich leczenie jest kosztowne właśnie ze względu na rzadkość ich występowania. Drugi to choroby oporne, których koszt leczenia jest relatywnie wysoki w stosunku do efektów zdrowotnych w postaci wzrostu jakości życia [19].

Istotną kwestią związaną z równością jest kwestia prawa do publicznej opieki zdrowotnej. Pierwszą wątpliwością dotyczącą istnienia tego prawa jest brak możliwości roszczenia sądowego w przypadku nieotrzymania świadczenia w odpowiednim i oczekiwanym przez siebie czasie.

Jaki wymiar czasowy można nazwać odpowiednim i oczekiwanym? Rejestrujący się w celu otrzymania świadczenia pacjent nie zawsze jest w stanie to ocenić. Pacjent zgłaszający się na wizytę jest przekonany, że jego zgłoszenie się do lekarza jest uzasadnione. Niemniej potrzeba uzyskania świadczenia przez pacjenta może mieć charakter naglący (gdy stan zdrowia wymaga jak najszybszego udzielenia świadczenia). Dlatego też zdarzające się kilkuletnie okresy oczekiwania na operacje są faktycznym odroczeniem świadczenia. To odroczenie, czyli rozłożenie w czasie możliwości skorzystania z określonych świadczeń, stanowi więc faktyczne ograniczenie prawa do opieki zdrowotnej.

Niezbędne wydaje się określenie przez publicznego regulatora systemu limitu czasu oczekiwania na realizację świadczenia. Ze względu na ograniczenia finansowe i organizacyjne systemu niemożliwe jest uniknięcie takiego oczekiwania. Brak regulacji dotyczącej limitu oczekiwania w polskim systemie opieki zdrowotnej wydaje się sprzeczny z ustawowymi gwarancjami do opieki zdrowotnej, gdyż każde, nawet wyraźnie długie oczekiwanie można wtedy przedstawić jako konieczne ze względu na ograniczenia finansowe płatnika. Wydaje się, że pożądanym byłoby rozwiązanie stosowane w systemach niektórych państw i polegające na możliwości sfinansowania przez publicznego płatnika świadczenia uzyskanego w sektorze prywatnym (zwrot pacjentowi poniesionej opłaty).

\section{RÓWNOŚĆ W SYSTEMACH OPIEKI ZDROWOTNEJ}

Sposób finansowania systemu, czyli w rzeczywistości wybór modelu opieki zdrowotnej, należy do decydentów. Kwestia zakresu osób objętych zabezpieczeniem zdrowotnym w postaci równego dostępu do opieki zdrowotnej jest przejrzysta w zaopatrzeniowych systemach opieki zdrowotnej. Prawo do opieki zdrowotnej wynika w tych systemach z faktu tzw. rezydentury (obywatelstwa bądź legalnego pobytu w przypadku obywateli innych państw). W systemach ubezpieczeniowych czy też mieszanych kwestia ta jest bardziej skomplikowana, gdyż prawo obywatela do opieki zdrowotnej wynika z tytułu bycia osobą ubezpieczoną bądź współubezpieczoną. Decydenci systemów opieki zdrowotnej określając okoliczności nabycia podmiotowego prawa do świadczeń finansowanych ze środków publicznych, powinni więc zmierzać do ustanowienia powszechnego charakteru tego prawa.

Przykładem rozbieżności między ustawą zasadniczą a ustawą regulującą system opieki zdrowotnej jest obowiązujący w Polsce system ubezpieczeniowo-zaopatrzeniowy. Wspomniany art. 68 Konstytucji zakłada równy dostęp dla każdego obywatela, a nie tylko dla osób mających tytuł do ubezpieczenia. Tę rozbieżność w swym wyroku nakazał usunąć Trybunał Konstytucyjny (TK), stwierdzając niekonstytucyjność ustawy o powszechnym ubezpieczeniu w Narodowym Funduszu Zdrowia (NFZ) [20].

W związku z wyrokiem TK uchwalono ustawę o świadczeniach opieki zdrowotnej finansowanej ze środków publicznych rozszerzającą zakres praw podmiotowych. Ustawa, doprecyzowując zapis art. 3 Konstytucji, wymienia dodatkowe grupy osób, które powinny mieć zapewniony dostęp do opieki zdrowotnej (nawet mimo braku tytułu do ubezpieczenia). Są to osoby które nie ukończyły 18. r.ż. (dzieci niezgłoszone do ubezpieczenia) oraz kobiety w okresie ciąży, porodu i połogu. Ustawa określa także prawo do opieki osób niebędących obywatelami polskimi [21] (którego to prawa nie określiła wyraźnie Konstytucja).

Możliwość dostępu do świadczeń dla osób nieubezpieczonych przewidują też inne ustawy: Ustawa o zapobieganiu oraz zwalczaniu zakażeń i chorób zakaźnych u ludzi z 5 grudnia 2008 r. (DzU nr 234, poz. 1570 ze zm.), Ustawa o ochronie zdrowia psychicznego z 19 sierpnia 1994 r. (DzU nr 111, poz. 535 ze zm.) oraz Ustawa o Karcie Polaka z 7 września 2007 r. (DzU nr 180, poz. 1280 ze zm.) [22].

Argument za jak najszerszą grupą osób objętych prawem podmiotowym jest dodatkowo wzmocniony zapisem zawartym we wspomnianym art. 12 Międzynarodowego Paktu Praw Gospodarczych, Socjalnych i Kulturalnych.

Pomimo wspomnianych rozszerzeń praw podmiotowych w polskim systemie nadal niektóre kategorie osób niezgłoszonych do ubezpieczenia z innego tytułu nie mają prawa do opieki zdrowotnej. Są to osoby bezdomne, bezrobotne bądź pracujące w „szarej strefie” i niezarejestrowane w powiatowych urzędach pracy, a także osoby zatrudnione za granicą i przebywające na stałe w Polsce.

\section{RÓWNOŚĆ W ZAKRESIE PRZEDMIOTOWYM}

Równość w zakresie przedmiotowym w ramach opieki finansowanej ze środków publicznych powinna oznaczać dostęp 
do niej na takich samych warunkach dla wszystkich pacjentów. Prawo do opieki zdrowotnej, wynikające w polskim systemie z Konstytucji, i związana z nim równość mają więc charakter ogólny. Kwestia szczegółowego zakresu świadczeń objętych finansowaniem ze środków publicznych leży w kompetencji ustawodawcy (określenie koszyka świadczeń gwarantowanych), co reguluje art. 68 Konstytucji: „warunki i zakres udzielania świadczeń określa ustawa" [15]. Jako środki publiczne należy natomiast rozumieć te, które (niezależnie od źródła wpływu) są redystrybuowane przez instytucje publiczne (państwowe bądź samorządowe).

Z punktu widzenia odpowiedzialności państwa w polskim ustawodawstwie opieki zdrowotnej istotna wydaje się kwestia statusu właścicielskiego świadczeniodawców (podmiotów leczniczych). Odpowiedzialność państwa sugerowałaby, że głównie podmioty publiczne (w przypadku szpitali przede wszystkim samodzielne publiczne zakłady opieki zdrowotnej) mogłyby realizować obowiązek opieki zdrowotnej. Publiczna własność daje w pewnym stopniu gwarancję dostępu do opieki zdrowotnej (brak zagrożenia szpitala upadłością). Jednakże określenie statusu świadczeniodawców - nie w oparciu o strukturę własnościową i rodzaj organu założycielskiego, lecz o źródło finansowania (kontrakt z publicznym płatnikiem) - określałoby jako podmioty publiczne również spółki z większością lub całością udziałów prywatnych (skomercjalizowane bądź prywatne). Biorąc pod uwagę ten punkt widzenia, każdy świadczeniodawca mający podpisany z NFZ kontrakt na świadczenie usług zdrowotnych jest podmiotem publicznym. Ewentualną możliwość upadłości, która mogłaby być efektem procesów komercjalizacji bądź prywatyzacji na danym obszarze terytorialnym, zahamowała nowelizacja ustawy o działalności leczniczej z czerwca 2016 r. [23].

Wyznacznikiem równości jest także wspominany fakt uniezależnienia otrzymanego świadczenia od wniesionego wkładu finansowego. Przestrzeganie zasad równości oznacza więc, że osiągane dochody i stan zamożności nie mogą predysponować świadczeniobiorcy ani do szybszego dostępu, ani do szerszego zakresu otrzymanych świadczeń. W polskim systemie oznacza to w praktyce ograniczenie wprowadzenia mechanizmu współpłacenia pacjenta do świadczeń w publicznej opiece zdrowotnej (w formie bezpośrednich dopłat bądź pośrednio poprzez prywatne ubezpieczenia). Stanowiska takie wyraziły sądy.

Sąd Najwyższy zanegował możliwość wprowadzenia dodatkowego ubezpieczenia zdrowotnego obejmującego świadczenia znajdujące się poza koszykiem świadczeń gwarantowanych i udzielane przez świadczeniodawców objętych kontraktem z NFZ jako naruszające gwarancję równego dostępu do świadczeń opieki zdrowotnej „niezależnie od sytuacji materialnej”. Wprowadzenie takiego rozwiązania sąd uznał za dopuszczalne po szczegółowym i precyzyjnym określeniu świadczeń (konkretnych procedur) i rozdzieleniu ich na finansowane z ubezpieczenia powszechnego (obowiązkowego) i z ubezpieczenia prywatnego (dobrowolnego) [24].

Argumentem wskazującym na uzależnienie dostępu do świadczeń od sytuacji materialnej świadczeniobiorcy posłużył się także Naczelny Sąd Administracyjny, orzekając w sprawie dodatkowych opłat, które mogłyby przyspieszyć udzielenie świadczenia [25].

Określenie zakresu procedur finansowanych ze środków publicznych i oparcie dostępu do nich na czytelnych (takich samych dla wszystkich pacjentów) kryteriach wpływa na spełnienie przesłanek równości. Niemniej jednak dostęp do procedur niefinansowanych ze środków publicznych, a wykonywanych przez świadczeniodawcę finansowanego przez publicznego płatnika (który musiałby być oparty na kryterium finansowym), już by tę równość kwestionował.

Można domniemywać, że takie przesłanki stoją za oporem decydentów przed wprowadzaniem ubezpieczeń prywatnych bądź mechanizmów dopłacania za świadczenia w podmiotach publicznych. Również i w środowiskach naukowych postulat urynkowienia poprzez wprowadzenie wspomnianych wyżej rozwiązań spotyka się ze sprzeciwem.

Według Szewczyka wprowadzenie ubezpieczeń prywatnych mogłoby wpłynąć na wzrost nierówności, gdyż osoby o niskich dochodach (a więc zazwyczaj w gorszym stanie zdrowia) byłyby narażone na relatywnie większe współpłacenie za świadczenia niż osoby zamożniejsze (statystycznie zdrowsze) [26]. Ponadto równości nie sprzyja zwiększający się udział sektora prywatnego i fakt, że w niektórych państwach (także i w Polsce) pewna liczba lekarzy pracuje równocześnie w sektorze publicznym i prywatnym (uznając zapewne za priorytet zatrudnienie w tym drugim, gdyż jest bardziej dochodowy). Może to wpływać na wykorzystywanie sektora publicznego do nieoficjalnego subsydiowania sektora prywatnego, do którego dostęp jest przecież uzależniony od środków posiadanych przez pacjenta (szczególnie wtedy, jeśli dany świadczeniodawca nie jest finansowany przez płatnika publicznego) [27].

Kwestie równości dostępu do opieki zdrowotnej finansowanej ze środków publicznych komplikuje dodatkowo nowelizacja Ustawy o świadczeniach zdrowotnych finansowanych ze środków publicznych z 25 czerwca 2009 r. [28], która definiuje świadczenie gwarantowane jako finansowane w całości lub współfinansowane ze środków publicznych na zasadach i w zakresie określonych w ustawie. Sankcjonuje więc ona współpłacenie pacjenta. Co prawda współpłacenie dotyczy głównie świadczeń rzeczowych: leków, przedmiotów ortopedycznych i środków pomocniczych, a także leczenia uzdrowiskowego, niemniej jednak i tego rodzaju świadczenia zaliczane są do opieki finansowanej ze środków publicznych.

\section{PRAKTYCZNE ASPEKTY RÓWNOŚCI}

Według danych zawartych w Narodowym Programie Zdrowia, osoby niewykształcone, ubogie, bezrobotne oraz mieszkające w rejonach o niższej jakości środowiska naturalnego i ze słabo rozwiniętą infrastrukturą medyczną mają też gorszy dostęp do opieki zdrowotnej [29].

Podobne wnioski wynikały z monitorowania szpitali w brytyjskiej National Health Service. W 1980 r. przedstawiono tzw. 
raport Blacka, z którego wynikało, że sztandarowe założenie systemu, czyli równość w dostępie do opieki zdrowotnej, nie zostało zrealizowane. Dzieci (zarówno noworodki, jak i niemowlęta z tzw. najniższych grup społecznych) umierały znacznie częściej niż dzieci z grup lepiej sytuowanych. W przypadku chłopców poniżej 1. r.ż.śmiertelność w grupie najniższej była 5-krotnie wyższa niż w tzw. grupie najwyższej. Wśród osób dorosłych niezdolność do pracy była aż 6-krotnie wyższa w grupie pierwszej niż w grupie drugiej [30]. W raporcie z 2000 r. opisano z kolei nierówności w dostępie związane z miejscem zamieszkania i wynikające ze zróżnicowanej efektywności szpitali. Liczbę przedwczesnych zgonów związanych z brakiem równości oszacowano na 7500. Podobne doświadczenia wynikają z systemu kanadyjskiego, gdzie występowały znaczne różnice w dostępności do opieki specjalistycznej pomiędzy różnymi stanami [31].

Dochodzi więc do swoistego paradoksu polegającego na tym, że opieka zdrowotna finansowana ze środków publicznych, której zasadniczym celem jest realizacja zasady równości, przyczynia się do pogłębienia nierówności. Pomimo istniejącej formalnie równości tzw. dostępność do opieki zdrowotnej (obejmująca czas oczekiwania, materialne i niematerialne koszty uzyskania świadczenia oraz poczucie satysfakcji) jest więc zróżnicowana [32].

Rosnące koszty opieki zdrowotnej powodują, że zakres dostępnych świadczeń jest coraz mniejszy w stosunku do odczuwanych potrzeb zdrowotnych i możliwości systemu. Znaczna część wydatków (w Polsce ok. 30\%) [33] musi być więc finansowana bezpośrednio lub pośrednio ze środków prywatnych, co stawia pod znakiem zapytania istnienie równości w ochronie zdrowia.

\section{WNIOSKI}

Koncepcja równości szans i dystrybucja „każdemu według potrzeb" mają charakter deklaratywny ze względu na istotne mankamenty publicznej opieki zdrowotnej. Wydaje się więc, że w praktyce ewentualne wyrównanie szans w dostępie do opieki zdrowotnej powinno się przekładać przede wszystkim na podnoszenie ogólnej jakości standaryzowanej opieki zdrowotnej (ta sama kategoria świadczeń powinna być realizowana przez wszystkich świadczeniodawców na odpowiednim poziomie).

\section{PIŚMIENNICTWO}

1. Poździoch S. System zdrowotny. In: Czupryna A, Poździoch A, Ryś A, Włodarczyk C, editors. Zdrowie Publiczne - wybrane zagadnienia. Tom 1. 2nd ed. Kraków: Vesalius; 2000. p. 128.

2. Magnuszewska-Otulak G. Wybrane problemy polityki zdrowotnej w Polsce. Problemy Polityki Społecznej. Studia i Dyskusje 2013;2(21):85-107.

3. Gałuszka M. Standardy sprawiedliwości w polskim systemie opieki zdrowotnej: zagadnienia ekonomiczne i etyczne. Annales. Etyka w życiu gospodarczym 2005;8(1):247-57.

4. Zdrowie 21. Zdrowie dla wszystkich w XXI wieku. Podstawowe założenia polityki zdrowia dla wszystkich w Regionie Europejskim WHO.
Kopenhaga: Światowa Organizacja Zdrowia. Biuro Regionu Europejskiego. Państwowa Agencja Rozwiązywania Problemów Alkoholowych; 2014. http://www.parpa.pl/index.php/alkohol-w-europie/zdrowie-21-zdrowie-dla-wszystkich-who (31.03.2017).

5. Międzynarodowy Pakt Praw Gospodarczych, Socjalnych i Kulturalnych. DzU z 1977 r., nr 38 poz. 169. http://prawo.sejm.gov.pl/isap.nsf/DocDetails.xsp?id=WDU19770380169\&type=1 (18.02.2017).

6. Konwencja o prawach dziecka przyjęta przez Zgromadzenie Ogólne Narodów Zjednoczonych dnia 20 listopada 1989 r. DzU z 1991 r., nr 120, poz. 526. http://www.prawo.egospodarka.pl/akty/dziennik-ustaw/1991/120/526 (18.02.2017).

7. Konwencja w sprawie likwidacji wszelkich form dyskryminacji kobiet, przyjęta przez Zgromadzenie Ogólne Narodów Zjednoczonych dnia 18 grudnia 1979 r. DzU z 1982 r., nr 10, poz. 71. http://webcache. googleusercontent.com/search?q=cache:_ZEifElFVG4J:niebieskalinia.info/pliki/dokumenty/Wa\%25C5\%25BCne\%2520dokumenty/ Konwencja\%2520w\%2520sprawie\%2520likwidacji\%2520wszelkich\%2520form\%2520dyskryminacji\%2520kobiet\%2520z\%2520dnia$\% 252018 \% 2520$ grudnia\%25201979\%2520roku.pdf $+\& \mathrm{~cd}=1 \& \mathrm{hl}=$ pl\&c$\mathrm{t}=\mathrm{clnk} \& \mathrm{gl}=\mathrm{pl}(18.02 .2017)$.

8. Konwencja o prawach osób niepełnosprawnych z 13 grudnia 2006 r. Rezolucja Zgromadzenia Ogólnego Narodów Zjednoczonych nr 61/106. DzU z 2012 r., poz. 1169.

9. International Convention on the Protection of the Rights of All Migrant Workers and Members of their Families. http://www.unesco.org/most/ migration/mwc_toc.htm/ (31.03.2017).

10. Konwencja dotycząca statusu uchodźców sporządzona w Genewie dnia 28 lipca 1951 r. DzU z 1991 r., nr 119, poz. 515 i 517. https://webcache. googleusercontent.com/search?q=cache:zt4NfbW2L2kJ:https://www. spoleczenstwoobywatelskie.gov.pl/sites/default/files/konwencja_genewska.pdf $+\& \mathrm{~cd}=1 \& \mathrm{hl}=$ pl\&ct=clnk\&gl=pl (31.03.2017).

11. Europejska Karta Społeczna sporządzona w Turynie dnia 18 października 1961 r., z późn. zm. DzU z 1999 r., nr 8, poz. 67. http:// prawo.sejm.gov.pl/isap.nsf/DocDetails.xsp?id=WDU19990080067 (18.02.2017)

12. Zmniejszanie nierówności zdrowotnych w Unii Europejskiej. Społeczna Europa. Komisja Europejskejska. Luksemburg: Urząd Publikacji Unii Europejskiej; 2011. http://webcache.googleusercontent. com/search?q=cache:-6pvsiaYRigJ:archiwum.efs.lubelskie.pl/widget/file/get/1302163439965860.pdf $+\& \mathrm{~cd}=1 \& \mathrm{hl}=\mathrm{pl} \& \mathrm{ct}=\mathrm{clnk} \& \mathrm{gl}=\mathrm{pl}$ (31.03.2017).

13. Deklaracja warszawska. Miesięcznik Okręgowej Izby Lekarskiej Puls 2007. http://www.oil.org.pl/xml/oil/oil68/gazeta/numery/n2008/n200801/ n20080111 (31.03.2017).

14. Dyrektywa Parlamentu Europejskiego i Rady 2011/24/UE z dnia 9 marca 2011 r. w sprawie stosowania praw pacjentów w transgranicznej opiece zdrowotnej. DzU UE L z dnia 4 kwietnia 2011.88.45.

15. Konstytucja Rzeczpospolitej Polskiej z 2 kwietnia 1997 r. DzU z 1997 r., nr 78, poz. 483. Prawo. Sejm. http://prawo.sejm.gov.pl/isap.nsf/DocDetails.xsp?id=WDU19970780483\&type $=3$ (31.03.2017).

16. Tołłoczko T. Leczenie chorych i liczenie pieniędzy. Równość szans czy większa skuteczność? In: Basińska K, Halasz J, editors. Etyka w medycynie - wczoraj i dziś. Wybrane zagadnienia. Kraków: Impuls; 2013. p. 321.

17. Beauchamp JT, Childress J. Zasady etyki medycznej. Warszawa: Książka i Wiedza; 1996. p. 341-58.

18. Włodarczyk WC. Współczesna polityka zdrowotna. Wybrane zagadnienia. 2nd ed. Warszawa: Lex Wolters Kluwer Business; 2014. p. 194.

19. Galewicz W. Etyczne problemy wobec ekonomicznych uwarunkowań współczesnej medycyny. In: Basińska K, Halasz J, editors. Etyka w medycynie - wczoraj i dziś. Wybrane zagadnienia. Kraków: Impuls; 2013. p. 316-7.

20. Wyrok Trybunału Konstytucyjnego z dnia 7 stycznia 2004 r. Sygn. akt K 14/03. DzU z 2004 r., nr 5, poz. 37. http://dziennikustaw.gov.pl/ DU/2004/s/5/37 (31.03.2017).

21. Ustawa z dnia 27 sierpnia 2004 r. o świadczeniach opieki zdrowotnej finansowanych ze środków publicznych. DzU z 2004 r., nr 210, poz. 2135. http://prawo.sejm.gov.pl/isap.nsf/DocDetails.xsp?id=WDU20042102135 (31.03.2017).

22. Lach DE. Zasada równego dostępu do świadczeń opieki zdrowotnej. Warszawa: Wolters Kluwer Polska; 2011. p. 168-73. 
23. Ustawa z dnia 10 czerwca 2016 r. o zmianie ustawy o działalności leczniczej oraz niektórych innych ustaw. DzU z 2016 r., poz. 960. http://dziennikustaw.gov.pl/du/2016/960/1/ (31.03.2017).

24. Orzeczenie Sądu Najwyższego. Wyrok z dnia 9 czerwca 2005 r., III CK 626/04. https://mojepanstwo.pl/dane/sn_orzeczenia/8661,iii-ck-626-04 (31.03.2017).

25. Wyrok Naczelnego Sądu Administracyjnego z 1 lutego 2006 r., II OSK 720/05. NSA. Centralna Baza Orzeczeń Sądów Administracyjnych. http:// orzeczenia.nsa.gov.pl/doc/FF41701298/ (31.03.2017).

26. Szewczyk K. Medycyna i finanse. Czy ekonomiczne racjonowanie świadczeń zdrowotnych jest sprawiedliwe? Diametros 2005;5:83-97.

27. Klich J. Systemowe ograniczenia funkcjonowania sektora publicznego w polskim systemie ochrony zdrowia. Studia i Materiały Polskiego Stowarzyszenia Zarząd zania Wiedzą 2011;54:249-58.

28. Jarosz-Żukowska S. Prawo do ochrony zdrowia i dostępu do świadczeń opieki zdrowotnej. In: Jabłoński M, editor. Realizacja i ochrona konstytucyjnych wolności i praw jednostki w polskim porządku prawnym.
Wrocław: Prace Naukowe Wydziału Prawa, Administracji i Ekonomii Uniwersytetu Wrocławskiego; 2014. p. 659-89.

29. Różnice społeczne i terytorialne w stanie zdrowia populacji. Narodowy Program Zdrowia na lata 2007-2015. Załącznik do Uchwały nr 90/2007 Rady Ministrów z dnia 15 maja 2007 r.p. 13-6. http://webcache.googleusercontent.com/search?q=cache:WIDT_Rau-kgJ:www.nationalplanningcycles.org/sites/default/files/country_docs/Poland/nhp_polen.pdf+\&c$\mathrm{d}=1 \& \mathrm{hl}=\mathrm{pl} \& \mathrm{ct}=\mathrm{clnk} \& \mathrm{gl}=\mathrm{pl}(31.03 .2017)$.

30. Sygit M. Zdrowie publiczne. Warszawa: Wolters Kluwer Polska; 2010. p. 432-3.

31. Goodman JC, Musgrave GL, Herrick DM. Jak uzdrowić służbę zdrowia. Raport o światowych systemach opieki zdrowotnej. Chicago: Fijor Publishing; 2008. p. 65-8.

32. Miller M, Opolski J. Bezpieczeństwo zdrowotne-zakres i odpowiedzialność. Probl Hig Epidemiol 2006;87(1):1-5.

33. Skrzypczak Z. Skala obciążeń polskiego społeczeństwa wydatkami na ochronę zdrowia. Zdr Pub 2010;120(2):107-11. 